New Researches into the Composition and Exegesis of the Koran, published by our Society in 1902 ; Sketch of Hebrew Grammar (1913); Quirquisani Studies (1918); Commentary on Deuteronomy (1925), and among his bibliographical writings, a Descriptive Catalogue of the Hebrew MSS. of the Montefiore Library (1904).

A number of his essays and reviews appeared in this and other Oriental journals.

M. GASTER.

\title{
Berthold Laufer
}

The tragic death of Dr. Berthold Laufer on 13th September, 1934, has robbed the world of a fine scholar and a charming and sympathetic personality.

"Dr. Laufer was born in Cologne on 11th, October, 1874. $\mathrm{He}$ was educated at a Cologne gymnasium, the University of Berlin, and the Seminary for Oriental Languages in Berlin. In 1897 he earned the degree of Doctor of Philosophy at the University of Leipzig. He came to the United States in 1898 and soon gained high repute as an ethnologist and anthropologist. Between 1899 and 1904 he conducted expeditions among the native tribes of Siberia and in China. For several years he served as a lecturer on anthropology and Asiatic languages at Columbia University. In 1907 he joined the staff of the Field Museum and in a short time became Associate Curator of Anthropology. Since 1915 he had been Curator of the Department. In recognition of his important researches and other work he was recipient of many honors from learned societies, Universities, and other scientific organizations." 1

Laufer's principal field of research was in the Far East. Some of his earliest published work deals with Tibetan and Mongolian subjects, but he is best known in Europe for his numerous publications on Chinese art and archæology.

1 From the Field Museum News, October, 1934. I am indebted to Professor Yetts for drawing attention to this article and to other items of information used in this notice. 
His book on Chinese Pottery of the Han Dynasty published in 1909 brought him world-wide and well deserved recognition. It was the first serious attempt to investigate the early phases of Chinese ceramic history, and it remains to this day a standard work. Chinese Grave-sculpture of the Han Period (1911) and Chinese Clay Figures (1914) werefurther scholarly contributions. But probably his great work on Jade (1912) has done most to spread Laufer's reputation in Europe. It is the book to which all students of jade have had recourse, and it is a characteristic work of the author, the fruit of painstaking research made palatable by a pleasant literary style and frequent touches of humour. In it Laufer based himself on Chinese text books which his good working knowledge of the language enabled him to read and quote, and his book is full of interesting information liberally illustrated. It is true that some of the authorities on which he relied at the time have suffered from subsequent criticism; but if Laufer had been spared he would certainly have published a revised edition of his $J a d e$ and have given us the authoritative book which we have all been awaiting with eager expectation. It is to be hoped that the material for this important work may yet be used by his literary executors.

His shorter monographs and articles range over a great variety of subjects and represent an immense amount of original work and research. The Beginnings of Porcelain in China (1917), Ivory in China (1925), Chinese Baskets (1925), Insect Musicians and Cricket Champions of China (1927), Paper and Printing in Ancient China (1931), The Lemon in China (1934), and The Swing in China, to mention only the definitely Chinese subjects on which he has given us the benefit of his extensive and peculiar information. In Laufer's works one was always apt to meet with surprises and some of his long, but far from tedious, digressions would have sufficed for separate monographs. Thus while the first part of his Chinese Clay Figures is mainly a discourse on the History of Defensive Armour (for this we are prepared by the sub-title), 
a hundred pages on the history of the rhinoceros present a totally unexpected interposition.

Interesting monographs other than the Chinese are his Turquois in the East (1913), Sino-Iranica (1919), Agate (1925), The Ostrich (1926), The Giraffe in History and Art (1928), The Pre-history of Aviation (1928), Introduction of Tobacco into Africa (1930), Early History of Polo (1932), and Felt (1933).

The bulk of his literary output appears in the publications of the Field Museum of Natural History, Chicago.

Laufer's long stays in the interior of China gave him an intimate understanding of Chinese habits and mentality, as his knowledge of the language allowed him to go back to original Chinese sources for his information on archæological matters. Thus equipped he was able to collect for the Field Museum material which is unrivalled in its scientific value, and to classify and explain it in admirable labels and handbooks. His work at the Field Museum and elsewhere places him in the front rank of Orientalists and Ethnographers, and the collections which he made and arranged will be a lasting monument to his name.

The list of his publications given above (though by no means complete) shows that Laufer was an indefatigable worker. Like many studious people he was inclined to be shy and sensitive ; but to those who had the privilege of his friendship he was warm-hearted and affectionate and a delightful and entertaining companion. I had only the good fortune to meet him once, in January, 1914, when I spent a few days at the Field Museum under his kindly guidance. But I carried away a lasting memory of his warm welcome, his untiring attentions, his inspiring zeal and withal of the modesty with which he imparted his profound knowledge.

8 .

R. L. Hobson. 